\title{
The Effect Of Intellectual, Emotional, And Spiritual Intelligence On The Economic Learning Achievement Of SMA Negeri 1 Soppeng
}

\author{
Muh. Yahya ${ }^{1}$, A. Mulyadi Radjab ${ }^{2}$, Satriyani $^{3}$ \\ 1,2,3 STKIP Pembangunan Indonesia (PI) Makasar, Indonesia \\ satrianisat10@yahoo.com
}

\begin{abstract}
This study aimed to examine the effect of intellectual intelligence on the students'learning achievement, the effect of emotional intelligence on the learning achievement students, the effect of spiritual intelligence on the learning achievement students, and stimulatingly examine the effect of intellectual, emotional, and spiritual intelligence on the economic learning achievement of students in SMA Negeri 1 Soppeng, Soppeng. Afterward, this study included as descriptive quantitative study. Population the study was all students of SMA Negeri 1 Soppeng which is 955 students. For the sample, 90 students were chosenusing simple random sampling technique. Further, data collection techniques used was questionnaire and documentation. Meanwhile, data analysis techniques used was descriptive analysis, analysis test requirements, and data analysis used SPSS 21 program. The result of this study showed that (1) intellectual intelligence variable significantly influenceon the economic learning achievement of students; (2) emotional intelligence variable significantly influencesthe economic learning achievement of students; (3) spiritual intelligence variable significantly effects the economic learning achievement of students; and (4) There was significant variables of intellectual, emotional, and spiritual intelligence on the economic learning achievement. Determination coefficient of X1, X2, and $\mathrm{X} 3$ to $\mathrm{Y}$ (r2Y.123) was 0,153 which showed that intellectual, emotional, spiritual intelligence factors have contribution to influence the economic learning achievement of students in SMA Negeri 1 Soppeng that was $15,3 \%$, while $84,7 \%$ was influenced by another variable that was not analyzed further.
\end{abstract}

Keywords: intellectual intelligence; emotional intelligence; spiritual intelligence.

History of Article:

Received : (03-12-2019),

Accepted : (31-01-2019),

Publised : (24-03-2020)

\section{Citation:}

Yahya, M., Radjab, A. M, \& Satriyani (2020) The Effect Of Intellectual, Emotional, And Spiritual Intelligence On The Economic Learning Achievement Of SMA Negeri 1 Soppeng, Jurnal Pendidikan Ekonomi, 13(1), 50-60

(C) Universitas Negeri Malang 


\section{INTRODUCTION}

The sophisticated knowledge and technology make the transformation of social culture to be complex. This reality on the one side encourages the growth of human civilization with the high-tech culture nuances, but on the other side, the transformation of various messages and all-new cultural pattern of knowledge and technology can comeback, especially for the society whose human resources are relatively low. Therefore, it is very naïve for such country that is willing to develop but the quality of knowledge and technology controlled by its country's youth is low.

Historical reality in the social-life in the world shows that various country which has low quality of human resources will be the object of imperialism influenced doctrine, even multi-dimension exploitation in the entire time by the country which has good quality of human resource. According to Habibah (2001) the negative effect that is appearing because of low human resource are many social problems, teenager crimes, stupidity, and many social anxieties. Nowadays, almost all the country over the world understand about that the historical reality. In the applicative system, many development countries, such as Indonesia, that still can not develop the quality of human resource yet. Even Indonesia is independent country, but the human resource of Indonesia mostly low.

Law number 20 of 2003 about National Education System article 1 verse 1 stated that education is a consciousness and planned effort to achieve the learning situation and learning process thatactively develop the potential to have a power, religious spiritual, good manner, and the good ability for her/his self, society, and country.

The education essence is preparing students through guidance, teaching and or training activities for their future roles. The future is the direction that is taken by starting from now. As the development country, the challenges that are faced are higher because of giving the basic education as a manifestation of the fulfillment of human right and also must catch up regarding the development of science and technology. Therefore, the education development policy is also directed to the equitable education.

The education quality can be measured by learning achievement of students' education output. Learning achievement is a result of learning process in the school. The low education quality can be detected by students' learning achievement in the school that can be an evaluation such as daily exam, mid exam, and final exam or final assessment. This evaluation is used to measure the competency ability of the students in the school. If the evaluation result is good, it means that students' learning achievement is good, however, if the evaluation result is low, it means that the learning achievement is bad. That is one of the measurements of intellectual intelligence.

Wiramiharja (2003) argued that since long ago, people believe that intellectual intelligence is a tool from the important mental ability for doing assignment or task. It can be understood since working is not about doing the task, but also the ability to solve the problem.

Learning achievement is not only seen by the intellectual intelligence, but also influenced by the ability of controlling or self-managing and the ability of having relation with each other. This ability, by Goleman (2000), through his study, stated that emotional intelligence supports $80 \%$ of the succeed determination factors, while $20 \%$ is decided by IQ (Intelligence Quotient).

People started to realize that not only intellectual superiority is needed to achieve success, but also to achieve success but needed another kind of skill to be leading edge. Thus, it is needed emotional intelligence. Goleman (2000) said that the ability to monitor and control her/ his own feeling and others' feeling as well as using this feeling to guide thought and action, so that the emotional intelligence is very needed to succeed in a work and produce prominent performance in a work. This opinion indicates that people who have emotional 
intelligence will be able to face challenges and make a human being full of responsibility, productive, and optimistic in dealing with and solving the problems, where those things are needed in the learning environment.

One of another intelligences that is popular is spiritual intelligence. Spiritual intelligence gives worship meaning to people towards each action and activity through the steps and good thought in regard to be the real human and has an integrality thought pattern as well as has a principle that is only God.

Spiritual intelligence appears because IQ (Intelligence Quotient) and EQ (Intelligence Quotient) is seen only donating a portion of the determinant of someone's success in life. There are other factors that play a role, namely intelligence spiritual which emphasizes the meaning of life and not only limited to religious emphasis. According to Marshal (2001) that spiritual intelligence is able to make people as an intellectually, emotionally, and spiritually complete creatures. The similar things were stated by Mudali (2002) that being smart is not only expressed by having a high IQ (Intelligence Quotient), but also having spiritual intelligence to be truly smart.

The latest condition in the mid of sophisticated information and technology is often happened the violence among the teenager such as students' brawl. Mostly, the students who were doing violence are students of senior high school. Students' brawl is not only involved the lazy one or the one who have a low learning achievement in the school, but also the diligent students who did it for solidarity. On the other hand, many students who have high IQ score but they addicted to drugs. This case that happened in the students of senior high school makes the decreasing of students' learning achievement. According to this problem, thus the writers are willing to examine further scientifically which entitled "The Effect of Intellectual, Emotional, Spiritual Intelligence on Economic Learning Achievement of SMA Negeri 1 Soppeng, Soppeng District by determining the study's location in SMA Negeri 1 Soppeng, Soppeng District, not only a district that is full of various culture, but also an education central in the East Sulawesi.

This study aimed to examine the effect of intellectual intelligence on the learning achievement students, the effect of emotional intelligence on the learning achievement students, the effect of spiritual intelligence on the learning achievement students, and stimulatingly examine the effect of intellectual, emotional, and spiritual intelligence on the economic learning achievement of students in SMA Negeri 1 Soppeng, Soppeng district.

\section{METHOD}

This study used descriptive quantitative. This study was conducted in SMA Negeri 1 Soppeng. The population of this study was all the students of SMA Negeri 1 Soppeng which was 955 students. The sample of this study consisted of 90 students by using simple random sampling technique. Technique of data collection used questionnaire and documentation. Technique of data analysis used descriptive analysis, requirement test analysis, and analysis data used SPSS 21 program.

\section{RESULT AND DISCUSSION}

Description of each variable such as intellectual, emotional, and spiritual intelligence can be seen in detail as follows:

\section{Intellectual Intelligence Variable}

Intellectual intelligence variable data was got from the questionnaires which consisted of 10 statements and filled by the participants which was about 90 students. Ideal score that was given was maximal 4 and minimal 1 on each statement item, thus it showed the highest ideal score is 40 and the lowest ideal score is 4 . According to data of study that is analyzed by using SPSS 21.0 program for windows, intellectual intelligence has the highest score of 
39 and the lowest score is 27 , mean of 31,27 , median is 32,00 , modus is 32 , and standard deviation is 1,606 . Completely data can be seen in the appendix 6 . The number of class interval is 7 classes, the class range is 12 , and the interval class length is 7,45 (rounded as 7). The frequency distribution table of intellectual intelligence as follows.

Table 1. Frequency Distribution of Intellectual Intelligence

\begin{tabular}{llll}
\hline No. & Interval & Frequency & Percentage (\%) \\
\hline 1 & $27-29$ & 6 & 6,70 \\
2 & $30-32$ & 71 & 78,90 \\
3 & $33-35$ & 11 & 12,20 \\
4 & $36-38$ & 1 & 1,10 \\
5 & $39-41$ & 1 & 1,10 \\
6 & $42-44$ & 0 & 0,00 \\
7 & $45-47$ & 0 & 0,00 \\
& Total & 90 & 100,00 \\
\hline
\end{tabular}

Source: Primary Data after Analyzing

After knowing the distribution frequency table, that is also created the table of trends score of spiritual intelligence variables, namely to find out the range of scores and the number of respondents included in the low, medium, and high categories. Based on the calculation, the ideal mean (Mi) is obtained at 33,0 and the ideal standard deviation (SDi) is 2,0 , whereas the ideal highest score is 40 and the ideal lowest score is 4 . The categorizing guideline of intellectual intelligence variable trends score that is already been modified is as following.

Table 2. The Categorizing Guideline of Intellectual Intelligence Variable Trends Score

\begin{tabular}{llll}
\hline No & Category & Formula & Accumulation \\
\hline 1 & High & $X>M i+1 S D i$ & $X>35.00$ \\
2 & Medium & $(M i-1 S D i) \leq X<(M i+S D i)$ & $31,00 \leq X<35.00$ \\
3 & Low & $X<M i-1 S D i$ & $X<31,00$ \\
\hline Source:
\end{tabular}

Source: Table 1

Table of trends score of intellectual intelligence can be seen below.

Table 3. Intellectual Intelligence Level

\begin{tabular}{lllllll}
\hline No & Category & Interval & Frequency & Percentage & $\begin{array}{l}\text { Frequency } \\
\text { Accumulation }\end{array}$ & $\begin{array}{l}\text { Frequency } \\
\text { Accumulation } \\
(\%)\end{array}$ \\
\hline 1 & High & $X>35.00$ & 2 & 2,22 & 90 & 100,00 \\
2 & Medium & $31,00 \leq X<36,00$ & 63 & 70,0 & 88 & 97,78 \\
3 & Low & $X<31,00$ & 25 & 27,78 & 25 & 27,78 \\
\hline
\end{tabular}

Source: Table 1

By looking at the table of trends score of intellectual intelligence variable can be said that score of intellectual intelligence in SMA Negeri 1 Soppeng is medium.

\section{Emotional Intelligence Variable}

Emotional intelligence variable data was got from the questionnaires which consisted of 36 statements and filled by the participants which was about 90 students. Ideal score that was given was maximal 4 and minimal 1 on each statement item, thus it showed the highest ideal score is 144 and the lowest ideal score is 36 . According to data of study that is analyzed by using computer, SPSS 21.0 program for windows, spiritual intelligence has the highest score of 140 and the lowest score is 104 , mean of 112,87, median is 113,00 , modus is 113 , and standard deviation is 4,283. Completely data can be seen in the appendix 6 . The number 
of class interval is 7 classes, the class range is 36 , and the interval class length is 4,83 (rounded as 5). Distribution table of emotional intelligence frequency as follows.

Table 4. Frequency Distribution of Emotional Intelligence

\begin{tabular}{llll}
\hline No. & Interval & Frequency & Percentage $(\%)$ \\
\hline 1 & $104-109$ & 11 & 12,20 \\
2 & $110-115$ & 6 & 73,30 \\
3 & $116-120$ & 10 & 11,10 \\
4 & $121-126$ & 2 & 2,20 \\
5 & $127-132$ & 0 & 0,00 \\
6 & $133-138$ & 0 & 0,00 \\
7 & $139-144$ & 1 & 1,10 \\
& Total & 90 & 100,00 \\
\hline
\end{tabular}

Source: Primary data after Analyzing

After knowing the distribution frequency table, that is also created the table of trends score of emotional intelligence variables, namely to find out the range of scores and the number of respondents included in the low, medium, and high categories. Based on the calculation, the ideal mean (Mi) is obtained at 122,0 and the ideal standard deviation (SDi) is 6,0, whereas the ideal highest score is 144 and the ideal lowest score is 36 . The categorizing guideline of emotional intelligence variable trends score that is already been modified is as following.

Table 5. Emotional Intelligence Level

\begin{tabular}{ccccccc}
\hline No & Category & Interval & Frequency & Percentage & $\begin{array}{l}\text { Frequency } \\
\text { Accumulation }\end{array}$ & $\begin{array}{l}\text { Frequency } \\
\text { Accumulation } \\
(\%)\end{array}$ \\
\hline 1 & High & $X>113$ & 1 & 1,11 & 90 & 100,00 \\
2 & Medium & $110 \leq X<113$ & 12 & 13,3 & 89 & 98,89 \\
3 & Low & $X<110$ & 77 & 85,56 & 77 & 85,56 \\
\hline \multicolumn{2}{l}{ Source: Table 3} & & & & &
\end{tabular}

By looking at the table of trends score of emotional intelligence variable can be said that score of emotional intelligence in SMA Negeri 1 Soppeng is high.

\section{Spiritual Intelligence Variable}

Spiritual intelligence variable data was got from the questionnaires which consisted of 21 statements and filled by the participants which was about 90 students. Ideal score that was given was maximal 4 and minimal 1 on each statement item, thus it showed the highest ideal score is 84 and the lowest ideal score is 21 . According to data of study that is analyzed by using computer, SPSS 21.0 program for windows, spiritual intelligence has the highest score of 79 and the lowest score is 62 , mean of 66,24 , median is 66,0 , modus is 66 , and standard deviation is 3,185 . Completely data can be seen in the appendix 6 . The number of class interval is 7 classes, the class range is 17 , and the interval class length is 1,21 (rounded as 1). Distribution table of spiritual intelligence frequency as follows.

\section{Table 6. The Frequency Distribution of Spiritual Intelligence}

\begin{tabular}{llll}
\hline Number & Interval & Frequency & Percentage $(\%)$ \\
\hline 1 & $62-64$ & 24 & 26.7 \\
2 & $65-67$ & 50 & 55.6 \\
3 & $68-70$ & 11 & 12.2 \\
4 & $71-73$ & 1 & 1.1 \\
5 & $74-76$ & 0 & 0.0 \\
6 & $77-79$ & 4 & 4.4 \\
7 & $80-82$ & 0 & 0.0
\end{tabular}


Source: Primary Data after Analyzing

After knowing the distribution frequency table, that is also created the table of trends score of spiritual intelligence variables, namely to find out the range of scores and the number of respondents included in the low, medium, and high categories. Based on the calculation, the ideal mean (Mi) is obtained at 70,50 and the ideal standard deviation (SDi) is 2,83 , whereas the ideal highest score is 84 and the ideal lowest score is 21 . The guideline for categorizing the tendency of the modified spiritual intelligence variable score is as following.

Table 7. Trends Level of Spiritual Intelligence Score

\begin{tabular}{|c|c|c|c|c|c|c|}
\hline No & Category & Interval & Frequency & Percentage & $\begin{array}{l}\text { Frequency } \\
\text { Accumulation }\end{array}$ & $\begin{array}{l}\text { Frequency } \\
\text { Accumulation }(\%)\end{array}$ \\
\hline 1 & High & & 4 & 4,44 & 90 & 100 \\
\hline 2 & Medium & & 24 & 26,67 & 86 & 95,56 \\
\hline 3 & Low & & 62 & 68,89 & 62 & 68,89 \\
\hline
\end{tabular}

Source: Table 5

By looking at the table of trends score of spiritual intelligence variable can be said that score of spiritual intelligence in SMA Negeri 1 Soppeng is low.

\section{Learning Achievement Variable}

Variable data of students' economic learning achievement is got from the final score in the even semester of 2017/2018 which the number of students is 90 . The highest score is 97 and the lowest score is 82 . According to data of study that is analyzed by using computer, SPSS 21.0 program for windows, students' economic learning achievement variable has mean of 66,24 , median is 87,82 and standard deviation is 2,897 . Completely data can be seen in the appendix 7. The number of class interval is 7 classes, the class range is 15 , and the interval class length is 2,01 (rounded as 2). Here is the table of frequency distribution on students' economic learning achievement.

Table 8. Frequency Distribution of Students' Economic Learning Achievement Score in SMA Negeri 1 Soppeng

\begin{tabular}{llll}
\hline Number & Interval & Frequency & Percentage (\%) \\
\hline 1 & $82-84$ & 3 & 3,3 \\
2 & $85-87$ & 43 & 47,8 \\
3 & $88-90$ & 32 & 35,6 \\
4 & $91-93$ & 8 & 8,9 \\
5 & $94-96$ & 3 & 3,3 \\
6 & $97-99$ & 1 & 1,1 \\
7 & $100-102$ & 0 & 0,0 \\
& Total & 90 & 100,00 \\
\hline
\end{tabular}

Source: Primary Data after Analyzing

After knowing the distribution frequency table, that is also created the table of trends score of economic learning achievement variables, namely to find out the range of scores and the number of respondents included in the low, medium, and high categories. Based on the calculation, the ideal mean (Mi) is obtained at 89,50 and the ideal standard deviation (SDi) is 2,50, whereas the ideal highest score is 97 and the ideal lowest score is 82 . The guideline for categorizing the tendency of the modified spiritual intelligence variable score is as following. 
Table 8. The Categorizing Guideline of Students' Economic Learning Achievement Variable

\begin{tabular}{|c|c|c|c|c|c|c|}
\hline No & Category & Interval & Frequency & Percentage & $\begin{array}{l}\text { Frequency } \\
\text { Accumulation }\end{array}$ & $\begin{array}{l}\text { Frequency } \\
\text { Accumulation } \\
(\%)\end{array}$ \\
\hline 1 & High & $x>92.0$ & 8 & 8.89 & 90 & 100 \\
\hline 2 & Medium & $x \geq 87,0$ & 48 & 53,33 & 82 & 91,11 \\
\hline 3 & Low & $X<87,0$ & 34 & 37,78 & 34 & 37,78 \\
\hline
\end{tabular}

Source: Table 7

By looking at the table of trends score of students' economic learning achievement variable can be said that score of spiritual intelligence in SMA Negeri 1 Soppeng is medium.

\section{Hypothesis Tests}

Hypothesis is a temporarily answer of those problems which have already been listed. This hypothesis must be tested the truth empirically. The hypothesis test of this study is conducted by simply regression analysis for the first and second hypothesis, however, multiple regression analysis is used for the third hypothesis. The explanation of the hypothesis test result is as following:

\section{The First Hypothesis}

The first hypothesis that will argue in this study is the hypothesis that is proposed against the economic learning outcomes in SMA Negeri 1 Soppeng students. To answer this hypothesis, the writer used simple regression analysis. Based on research data processed using computer assistance, the SPSS 21.00 for windows program, the results of a simple regression analysis are as follows.

Table 9. Outline of Simply Linear Regression

\begin{tabular}{llllllll}
\hline Model & S & R & R & T & t & P & Notes. \\
\hline Constanta & 100.178 & & & & & & \\
Intellectual & .395 & .219 & .048 & 2.106 & 1.980 & .038 & Significant \\
Variable & & & & & & & \\
\hline $\begin{array}{l}\text { Source: Primary Data } \\
\text { after Analyzing }\end{array}$ & & & & &
\end{tabular}

Based on the discussion above, the regression line equation can be expressed in the equation as follows:

$$
\mathrm{Y}=100,178+0.395 \mathrm{X} 1
$$

The equation shows that value the regression coefficient is positive at 0.395 which means if intellectual intelligence (X1) increases by one unit, then the value of student economic learning achievement (Y) will increase by 0.395 units.

Based on the results of the analysis using SPSS 21.00 for windows, it shows that the correlation coefficient X1 against $\mathrm{Y}(\mathrm{rx} 1, \mathrm{y})$ is 0.219 because the correlation coefficient (rx1, y) is positive, it can be seen that there is a positive relationship between intellectual intelligence variables and economic learning achievement of Soppeng 1 Public High School students. As per the sample data $(n=90)$, if intellectual intelligence increases, student learning achievement also increases and vice versa, so it can be said that the relationship between the variables of intellectual intelligence and student achievement is in the same direction.

The magnitude of the coefficient of determination is the square of the correlation coefficient (r2). This coefficient is called the determinant coefficient, because the variance that occurs in the dependent variable can be explained through the variance that occurs in the independent variable. Based on the results of the analysis using SPSS 21.00 for windows, the price of the coefficient of determination X1 against $\mathrm{Y}(\mathrm{r} 2 \mathrm{x} 1, \mathrm{y})$ is equal to0.048. This 
shows that the variableof Intellectual intelligence has an influence on the economic learning achievement of Soppeng 1 Public High School students at 4.8\% while 95.2\% is determined by other variables not examined. Significance testing aims to determine the significance of intellectual intelligence variables on student economic learning achievement. The hypothesis tested there is an influence of intellectual intelligence variables on economic learning achievement of Soppeng 1 Public High School students. Significance test using the test, based on the results of the $t$ test obtained by tcount of 2.106. When compared with the table of 2,306 at the significance level $5 \%$, then tcount is greater than $t$ table $(2,106>1,980)$ or $\mathrm{P}$ $(0.038<0.05)$ so that the intelligence variable has a significant influence on students' economic learning achievement.

\section{The Second Hypothesis}

The second hypothesis that will argue in this study is there is an effect on emotional intelligence of students' economic learning achievement in SMA Negeri 1 Soppeng. To answer this hypothesis, the writer used simple regression analysis. Based on research data processed using computer assistance, the SPSS 21.00 for windows program, the results of a simple regression analysis are as follows.

Table 10. Outline of Simply Linear Regression

\begin{tabular}{llllllll}
\hline Model & S & R & R & T & t & P & Notes \\
\hline Constanta & 71.099 & & & & & & \\
Emotional Variable & 0.148 & 0.219 & 0.048 & 1.106 & 1.980 & 0.038 & Significant \\
\hline
\end{tabular}

Based on the discussion above, the regression line equation can be expressed in the equation as follows:

$$
\mathrm{Y}=71,099+0.148 \mathrm{X} 2
$$

The equation shows that regression coefficient value is positive at 0.148 which means if intellectual intelligence (X2) increases by one unit, then the value of student economic learning achievement (Y) will increase by 0.148 units.

Based on the results of the analysis using SPSS 21.00 for windows, it shows that the correlation coefficient $\mathrm{X} 2$ against $\mathrm{Y}(\mathrm{rx} 2, \mathrm{y})$ is 0.219 because the correlation coefficient ( $\mathrm{rx} 2$, y) is positive, it can be seen that there is a positive relationship between intellectual intelligence variables and economic learning achievement of SMA Negeri 1 Soppeng students. As per the sample data $(n=90)$, if emotional intelligence increases, student learning achievement also increases and vice versa, so it can be said that the relationship between the variables of intellectual intelligence and student achievement is in the same direction.

The magnitude of the coefficient of determination is the square of the correlation coefficient ( $\mathrm{r} 2$ ). This coefficient is called the determinant coefficient, because the variance that occurs in the dependent variable can be explained through the variance that occurs in the independent variable. Based on the results of the analysis using SPSS 21.00 for windows, the price of the coefficient of determination $\mathrm{X} 2$ against $\mathrm{Y}(\mathrm{r} 2 \mathrm{x} 2, \mathrm{y})$ is equal to 0.048 . This shows that the variable of Intellectual intelligence has an influence on the economic learning achievement of SMA Negeri 1 Soppeng students at $4.8 \%$ while $95.2 \%$ is determined by other variables not examined.

Significance testing aims to determine the significance of emotional intelligence variables on student economic learning achievement. The hypothesis tested there is an influence of emotional intelligence variables on economic learning achievement of SMA Negeri 1 Soppeng students. Significance test using the $t$ test, based on the results of the test obtained by tcount of 1.106 . When compared with the table of 1,980 at the significance level 
$5 \%$, then tcount is greater than $\mathrm{t}$ table $(1,106>1,980)$ or $\mathrm{P}(0.038<0.05)$ so that the emotional variable has a significant influence on students' economic learning achievement

\section{The Third Hypothesis}

The second hypothesis that will argue in this study is there is an effect on spiritual intelligence of students' economic learning achievement in SMA Negeri 1 Soppeng. To answer this hypothesis, the writer used simple regression analysis. Based on research data processed using computer assistance, the SPSS 21.00 for windows program, the results of a simple regression analysis are as follows.

Table 11. Outline of Simply Linear Regression

\begin{tabular}{|c|c|c|c|c|c|c|c|}
\hline Model & $\mathrm{S}$ & $\mathrm{R}$ & $\mathrm{R}$ & $\mathrm{T}$ & $\mathrm{T}$ & $\mathrm{P}$ & Notes \\
\hline $\begin{array}{l}\text { Constanta } \\
\text { Emotional } \\
\text { Variable }\end{array}$ & $\begin{array}{l}100,672 \\
0,194\end{array}$ & 0,213 & 0,045 & 2,047 & 1,980 & 0,044 & Significant \\
\hline
\end{tabular}

Based on the discussion above, the regression line equation can be expressed in the equation as follows:

$$
\mathrm{Y}=100,672+0.194 \mathrm{X} 3
$$

The equation shows that regression coefficient value is positive at 0.148 which means if intellectual intelligence (X2) increases by one unit, then the value of student economic learning achievement (Y) will increase by 0.148 units.

Based on the results of the analysis using SPSS 21.00 for windows, it shows that the correlation coefficient X3 against $\mathrm{Y}(\mathrm{rx} 3, \mathrm{y})$ is 0.213 because the correlation coefficient ( $\mathrm{rx} 3$, y) is positive, it can be seen that there is a positive relationship between intellectual intelligence variables and economic learning achievement of SMA Negeri 1 Soppeng students. As per the sample data $(n=90)$, if emotional intelligence increases, student learning achievement also increases and vice versa, so it can be said that the relationship between the variables of intellectual intelligence and student achievement is in the same direction.

The magnitude of the coefficient of determination is the square of the correlation coefficient ( $\mathrm{r} 2$ ). This coefficient is called the determinant coefficient, because the variance that occurs in the dependent variable can be explained through the variance that occurs in the independent variable. Based on the results of the analysis using SPSS 21.00 for windows, the price of the coefficient of determination $\mathrm{X} 1$ against $\mathrm{Y}(\mathrm{r} 2 \mathrm{x} 3, \mathrm{y})$ is equal to 0.045 . This shows that the variable of Intellectual intelligence has an influence on the economic learning achievement of Soppeng 1 Public High School students at 4.5\% while 95.5\% is determined by other variables not examined.

Significance testing aims to determine the significance of intellectual intelligence variables on student economic learning achievement. The hypothesis tested there is an influence of spiritual intelligence variables on economic learning achievement of SMA Negeri 1 Soppeng students. Significance test using the $t$ test, based on the results of the test obtained by tcount of 2.047. When compared with the table of 1,980 at the significance level $5 \%$, then tcount is greater than t table $(2,047>1,980)$ or $\mathrm{P}(0.044<0.05)$ so that the spiritual variable has a significant influence on students' economic learning achievement. 


\section{The Fourth Hypothesis}

The fourth hypothesis that will argue in this study is there is an effect on intellectual, emotional, and spiritual intelligence of students' economic learning achievement in SMA Negeri 1 Soppeng To answer this hypothesis, the writer used simple regression analysis. Based on research data processed using computer assistance, the SPSS 21.00 for windows program, the results of a simple regression analysis are as follows.

Table 12. Outline of Simply Linear Regression

\begin{tabular}{llllllll}
\hline Model & Coefficient & $\mathbf{R}$ & $\mathbf{R}_{\mathbf{2}}$ & $\mathbf{t}$ & $\mathbf{t}_{\mathbf{0 . 0 5}}$ & $\mathbf{P}$ & Notes. \\
\hline Constanta & 95.114 & 0.391 & 0.153 & 2.257 & 1.980 & .027 & Significant \\
Intellectual & .405 & 0.391 & 0.153 & - & 1.980 & - & Significant \\
Intelligence & & & & & & & \\
Emotional Intelligence & .170 & 0.391 & 0.153 & 2.522 & 1.980 & .014 & Significant \\
ISpiritual Intelligence & .209 & 0.391 & 0.153 & 2.306 & 1.980 & .024 & Significant \\
\hline
\end{tabular}

Source: Primary Data after Analyzing

Based on the discussion above, the regression line equation can be expressed in the equation as follows:

$$
\mathrm{Y}=95,114+0,405 \mathrm{X} 1+0,170 \mathrm{X} 2+0,209 \mathrm{X} 3
$$

The equation shows that the regression coefficient of intellectual intelligence variable (X1) is 0.405 , which means that if the value of the intellectual intelligence variable (X1) increases by one unit, the economic learning achievement value (Y) will increase by 0.405 assuming $\mathrm{X} 2$ and $\mathrm{X} 3$ remain, the coefficient value Emotional intelligence regression (X2) is 0.170 which means that if the value of emotional intelligence (X2) increases by one unit, then the value of students' economic learning achievement (Y) will increase

0.170 units with the assumptions of $\mathrm{X} 1$ and $\mathrm{X} 3$ remain, as well as the coefficient of spiritual intelligence (X3) of 0.209 , which means that if the value of spiritual intelligence (X3) increases by one unit, the economic learning achievement of students (Y) will increase

0.209 units assuming X1 and X2 remain. Based on the results of the analysis using SPSS 21.00 for windows, it shows that the correlation coefficient X1, X2, X3 against Y (ry.123) is 0.391 because the correlation coefficient (ry.123) is positive, it can be seen that there is a positive relationship between intellectual intelligence variables and economic learning achievement of SMA Negeri 1 Soppeng students. As per the sample data $(\mathrm{n}=90)$, if intellectual, emotional, and spiritual intelligence increases, student learning achievement also increases and vice versa, so it can be said that the relationship between the variables of intellectual intelligence and student achievement is in the same direction.

The magnitude of the coefficient of determination is the square of the correlation coefficient (r2). This coefficient is called the determinant coefficient, because the variance that occurs in the dependent variable can be explained through the variance that occurs in the independent variable. Based on the results of the analysis using SPSS 21.00 for windows, the price of the coefficient of determination $\mathrm{X} 1, \mathrm{X} 2$, and $\mathrm{X} 3$ against $\mathrm{Y}$ ( $\mathrm{r} 2 \mathrm{y} .123$ ) is equal to 0.153. This shows that the variable of Intellectual intelligence has an influence on the economic learning achievement of Soppeng 1 Public High School students at 15.3\% while $84.7 \%$ is determined by other variables not examined.

Significance testing aims to determine the significance of intellectual, emotional, and spiritual intelligence variables on student economic learning achievement. The hypothesis tested there is an influence of intellectual, emotional, and spiritual intelligence variables on economic learning achievement of SMA Negeri 1 Soppeng students. Significance test using the F test, based on the results of the F test obtained by F count of 5.189. When compared with the table of 1,980 at the significance level $5 \%$, then $t$ count is greater than $t$ table $(5,189>$ $1,980)$ or $\mathrm{P}(0.002<0.05)$ so that the emotional variable have a significant influence on students' economic learning achievement. 


\section{CONCLUSION}

According to the result of study, it can be concluded that (1) The intellectual intelligence effect on economic learning achievement of students. It means that the ability of verbal, quantitative, and spatial was influence on the economic learning achievement of students; (2) The emotional intelligence effect on economic learning achievement of students. It means that the ability of personal intelligence such as management-self and consciousnessself, and self-motivation and social intelligence such as empathy and social awareness influenced the economic learning achievement of students; (3) The spiritual intelligence effect on economic learning achievement of students. It means that the relationship between God and society, attitude or akhlaq (ethic and moral) has effect on economic learning achievement of students.

This study recommended for the school-stakeholders to develop and optimize the intellectual, emotional, and spiritual intelligence which role on the students' achievement either in the school or another place. Since looking for data, the writer should collect the data of students' achievement on all their lessons, thus the final result would be the learning achievement comprehensively. Besides that, another writer can use various variables y using another intelligence variable except intellectual, emotional, and spiritual intelligence.

\section{REFERENCE}

Goleman. (2002). Emotional Intelligence. Jakarta: PT. Gramedia Pustaka Utama.

Habibah. (2001). Meningkatkan Kinerja Melalui Mekanisme 360 Derajat. Telaah Bisnis. 2(1) p.27-37.

Marshall, Danah Zohar Ian. (2001) SQ: Memanfaatkan Kecerdasan Spiritual dalam Berfikir Integralistik dan Holistik Untuk Memaknai Kehidupan. Bandung: Mizan.

Mudali. (2002) Quate: How High Is Yours Spiritual Intelligence. Online, [http://www.eng.usf.edu/gopalaks/articles/spiritual.html.15 Juni 2005]

Wiramiharja, S. A, (2003) Keeratan Hubungan Antara Kecerdasan, Kemauan dan Prestasi Kerja. Jurnal Psikologi. 11(1) 